\section{TANGGUNG JAWAB SOSIAL PENGELOLA PERUSAHAAN REAL ESTATE TERHADAP MASYARAKAT $^{1}$}

Oleh: Reggiannie Monintja

\section{ABSTRAK}

Tujuan dilakukannya penelitian ini adalah untuk mengetahui bagaimana implementasi tanggung jawab sosial perusahaan dan bagaimana keberadaan tanggung jawab sosial perusahaan perusahaan real estate di daerah Manado. Berdasarkan penggunaan metode penelitian normatif disimpulkan bahwa: 1 . Perlu adanya inisiatif dan perencanaan yang matang oleh perusahaan dalam melakukan tanggung jawab sosial, agar usaha yang dilakukan tepat pada sasaran serta memenuhi kebutuhan masyarakat dan lingkungan sekitar, serta penjelasan dan pemahaman yang lebih konkrit akan perusahaan yang berkaitan dengan sumber daya alam, agar tanggung jawab sosial dan lingkungan tidak hanya dititik beratkan kepada para pelaku usaha yang bergerak dibidang sumber daya alam tapi juga kepada perusahaan yang kegiatan usahanya berkaitan dengan sumber daya alam agar maksud dari Undang-Undang itu sendiri bisa diimplementasikan kepada kedua bidang usaha, yang sama-sama mempengaruhi keselarasan sosial dan lingkungan, walaupun dampaknya tidak sama. 2. Perlu adanya fungsi kontrol atau suatu badan pengawasan dari pemerintah maupun instatansi yang bersangkutan, terhadap perusahaan-perusahaan yang diwajibkan untuk melakukan tanggung jawab sosial dan lingkungan, agar para pelaku usaha bisa lebih terdorong lagi dalam menjalankan kewajiban mereka terhadap tanggung jawab sosial dan lingkungan, serta pelaksanaan saksi yang

\footnotetext{
${ }^{1}$ Artikel skripsi. Dosen Pembimbing Skripsi: Prof.Dr. Telly Sumbu, $\mathrm{SH}, \mathrm{MH}$, Drs. Frans Kalesaran, $\mathrm{SH}, \mathrm{MH}$, Drs. Munawir Djubedi,SH,MH.
}

konkrit ketika suatu perusahaan tidak melakukan tanggung jawab mereka dibidang sosial dan lingkungan.

Kata kunci: real estate

\section{PENDAHULUAN}

\section{A. LATAR BELAKANG PERMASALAHAN}

Kurangnya kontribusi dan pelaksanaan Tanggung Jawab Sosial Perusahaan bisa terlihat dari masalah-masalah lingkungan serta masalah antara masyarakat dan perusahaan yang timbul di Indonesia. Mulai dari kasus pencemaran lingkungan lumpur Lapindo di Porong dan pencemaran oleh P.T Newmont di Teluk Buyat, konflik masyarakat Papua dengan PT. Freeport Indonesia, konflik masyarakat Aceh dengan Exxon Mobile yang mengelola gas bumi di Arun dan permasalahan lainnya yang tentunya saling merugikan kedua belah pihak terutama masyarakat.

\section{B. PERUMUSAN MASALAH}

a. Bagaimana implementasi tanggung jawab sosial perusahaan?

b. Bagaimana keberadaan tanggung jawab sosial perusahaan perusahaan real estate di daerah Manado?

\section{METODE PENELITIAN}

Metode yang digunakan dalam penelitian tentang tanggung jawab pengelola perusahaan real estate merupakan deskriptif analisis. Dikatakan bersifat deskriptif karena dalam penelitian ini diharapkan akan memperoleh gambaran secara jelas tentang hal-hal yang berkaitan dengan permasalahan penelitian. Bersifat analitis karena akan dilakukan pembahasan secara sistematis, menyeluruh dan mendalam terhadap obyek permasalahan dalam rangka menjawab permasalahan penelitian.

\section{PEMBAHASAN}

\section{A. Implementasi Tanggung Jawab Sosial Perusahaan}


Implementasi tanggung jawab sosial perusahan merupakan merupakan pelaksanan dari UU PT dan Penanaman modal, bagaimana perusahaan mengimplemtasikan tanggung jawab sosial merupakan tolak ukur dari kesuksesan suatu Undang-Undang itu sendiri. Sesuai dengan pasal 4 ayat 1-2, Pasal 6 dan 7 PP No.40 Tahun 2012.

Pasal-Pasal di atas menjelaskan bahwa tanggung jawab sosial dan lingkungan harus dijalankan berdasarkan dengan suatu rencana kerja tahunan, dana untuk pelaksanaan tersebut diambil dari dana perseroan, pelaksanaannya sendiri harus dimuat dalam laporan tahunan perseroan dan bila perseroan tidak menjalankan tanggung jawab sosial maka akan dikenakan saksi sesuai dengan undangundang.

Adapun cara-cara bagaimana yang harus dilakukan perusahaan dalam mengimplemtasikan tanggung jawab sosial, yaitu:

\section{Perencanaan Tanggung Jawab Sosial Perusahaan}

Tanggung jawab sosial membutuhkan suatu perumusan yang jelas, baik materi, strategi, sasaran, penelitian pemangku kepentingan, maupun anggaran yang dibutuhkan. ${ }^{2}$ Dengan demikian, kualitas perancangan praktik tanggung jawab sosial perusahaan tergantung pada analisis perusahaan terhadap lingkungan sosial. ${ }^{3}$

Sebuah perancangan program menjadi penting karena dapat dijadikan arah untuk melaksanakan program itu sendiri, disamping itu perencanaan juga menentukan strategi yang lebih efektif dapat dilaksanakan. ${ }^{4}$ Paling tidak terdapat sembilan hal yang perlu diperhatikan dalam perumusan, antara lain: merumuskan visi

\footnotetext{
${ }^{2}$ Hadi. Nor, Op-cit, hal.123

${ }^{3}$ Ibid

${ }^{4}$ Wibisono, Yusuf, "Membedah Konsep dan Apikasi Corporate Sosial Responsibility", Fascho Publishing, Jawa Timur, 2007
}

misi, tujuan, kebijakan, merancang sruktur organisasi, menyiapkan SDM, membagi wilayah, mengelolah dana, rancang implementasi, evaluasi dan pelaporan. ${ }^{5}$

\section{a. Menetapkan Visi}

Visi merupakan landasan filosofis operasional suatu entitas, dengan tidak memandang jenis entitasnya (organisasi). Sebagai landasan filosofis visi menjadi core value satu aktivitas sehingga menjiwai berbagai bentuk aktivitas yang menjadi kebijakan entitas. Visilah yang akan memberikan arahan bagi para pihak pengelola perusahaan untuk menentuan code of conduct perushaan, agar sejalan dengan nilai masyarakat di lingkungannya. ${ }^{6}$

\section{b. Menetapkan Misi}

Misi merupakan penjabaran secara lebih operasional dari visi. Sehingga, misi tanggung jawab sosial perusahaan merupakan wahana untuk menginformasiakan siapa perusahaan, landasan filosofis perusahaan, apa inti atau garis aktivitas perusahaan dimata stakeholder. Di sini, misi menjadi pijakan untuk merumuskan tanggung jawab sosial yang akan dilakukan perusahaan. ${ }^{7}$

\section{c. Menetapkan Tujuan}

Tujuan merupakan scope hasil akhir yang dicapai perusahaan sebagaimana tertuang dalam perencanaan. Penentuan tujuan penting dalam banyak aktivitas meskipun belum dilakukan. Tujuan merumuskan apa yang akan diselesaikan oleh perusahaan dalam keberpihakan terhadap para pemangku kepentingan, dan kapan akan diselesaikan, serta mengukur secara akurat kegiatan yang akan dilakukan. ${ }^{8}$

\section{d. Menetapkan Target}

Target merupakan batas dan acuan ketercapaian pekerjaan jangka pendek dari tujuan yang telah ditetapkan sebelumnya. Dengan menetapkan target, para pelaksana

\footnotetext{
${ }^{5}$ Ibid

${ }^{6}$ Nor, Hadi, Op-cit, hal.124

${ }^{7}$ Ibid, hal.125

${ }^{8}$ Ibid
} 
tanggung jawab sosial, memiliki patokan dalam melaksanakan program yang bersangkutan. ${ }^{9}$

\section{e. Mempertimbangkan Kebijakan}

Kebijakan merupakan pedoman umum sebagai acuan pelaksanaan program tanggung jawab sosial perusahaan. Kebijakan merupakan arah dasar yang diambil pemimpin dan menjadi warna orientasi suatu program. ${ }^{10}$

\section{f. Menetapkan Strategi}

Menetapkan strategi implementasi tanggung jawab sosial memiliki ketergantungan arah mana kebijakan tanggung jawab sosial akan dilakukan. Strategi di sini merupakan cara untuk menjabarkan visi, misi, dan kebijakan tanggung jawab sosial yang akan dipraktikkan, antara lain dengan strategi sebagai berikut:

1) Public Relation, yaitu strategi yang ditujukan untuk untuk menanamkan presepsi masyarakat tentang perusahaan.

2) Strategi defensive, yaitu usaha yang dilakukan untuk menangkis atau mengubah anggapan negative yang telah tertanam dari komunitas terhadap masyarakat.

3) Community Development, yaitu program untuk komunitas sekitar perusahaan atau kegiatan perusahaan yang berbeda dari hasi perusahaan. ${ }^{11}$

\section{g. Merancang Struktur Organisasi}

Praktik tanggung jawab sosial perusahaan antara perusahaan berada dalam variance yang cukup besar. Dalam rangka menjaga pelaksanaan tanggung jawab sosial dilakukan secara serius, terencana, perlu bentuk suatu departemen yang secara khusus bertanggung jawab atas pelaksanaan tanggung jawab sosial. ${ }^{12}$

\footnotetext{
${ }^{9}$ Ibid, hal.126

${ }^{10}$ Ibid

${ }^{11}$ Ibid hal.130

${ }^{12}$ Ibid, hal 132
}

\section{h. Merancang Program}

Suatu aktivitas tanggung jawab sosial yang relatif krusial adalah ketepatan bentuk aktivitas dan keefektifan terhadap kemanfaatan dimata stakeholder dan lingkungan, serta koherensi dampak operasional perusahaan. ${ }^{13}$

\section{i. Menyediakan Sumber Daya Manusia}

Menyediakan sumberdaya manusia adalah pihak karyawan yang diserahkan tugas dalam pelaksanan aktivitas tanggung jawab sosial. ${ }^{14}$

\section{j. Penentuan Sumber Dana}

Menurut Undang-undang No.40 tahun 2007 menyatakan bahwa perusahaan di lingkungan BUMN dan perusahaan yang operasinya bersentuhan eksploitasi sumber daya alam harus menyisihkan sampai $3 \%$ untuk kegiatan bina lingkungan dan kemitraan. ${ }^{15}$

\section{k. Implementasi}

Implementasi tanggung jawab, berarti merencanakan implementasi pelaksanaan tanggung jawab sosial di lapangan. ${ }^{16}$

\section{Evaluasi Tanggung Jawab Sosial}

Dalam setiap program tanggung jawab sosial membutuhkan pemantauan dan evaluasi dalam rangka perbaikan di masa yang akan dating, dan sekaligus menentukan tingkat capaian kinerja aktivitas sosial yang telah dilakukan. Evaluasi dan pemantauan juga dilakukan untuk mengetahui sejauhmana pencapaian tujuan serta apakah terdapat penyimpangan yang membutuhkan tindakan koreksi. Terutama bagi tanggung jawab sosial yang bersifat multy years. Evaluasi pelaksanaan tanggung jawab sosial perusahaan dilakukan dalam rangka mencapai tujuan:

a. Memperoleh temuan masukan untuk perencanaan program atau kegiatan yang dilaksanakan

\footnotetext{
${ }^{13} \mathrm{Ibid}$

${ }^{14}$ Ibid, hal.37

${ }^{15}$ UU No. 40 tahun 2007

${ }^{16}$ Hadi, Nor. Op-cit, hal 141
} 
b. Memperoleh barbagai bahan pertimbangan dalam rangka mendukung pengambilan keputusan, layak atau tidak layak program tanggung jawab sosial dilanjutkan

c. Memperoleh temuan untuk masukan perbaikan program atau kegiatan yang sedang dilaksanakan

d. Memperoleh temuan hambatan program yang sedang dilaksanakan

e. Memperoleh temuan untuk perbaikan

f. Memperoleh rekomendasi dan pelaporan terhadap penyandang dana.

Implemantasi program tanggung jawab sosial didasarkan pada standar atau norma ketercapaian. Untuk itu, dalam rangka melakukan evaluasi perlu dirumuskan ukuran keberhasilan program antara lain: ${ }^{17}$

a. Indikator Internal

1)Ukuran Primer/Kualitatif (M-A-O terpadu)

a) Minimize

Meminimalkan perselisihan antara perusahaan dengan masyarakat dengan harapan terwujudnya hubungan yang harmonis dan kondusif.

b) Aset

Aset perusahaan yang terdiri dari pemilik atau pemimpin perusahaan, karyawan, pabrik dan fasilitas pendukungnya terjaga da terpelihara dangan aman.

c) Operasional

Seluruh kegiatan perusahaan berjalan dengan aman dan lancar.

2) Ukuran sekunder

a) Tingkat penyakuran dan kolektabilitas.

b) Tingkat Compliance pada aturan yang berlaku.

\section{b. Indikator Eksternal}

1) Indikator ekonomi

\footnotetext{
${ }^{17}$ Wibisono, Yusuf, Op-cit, hal.21
}

a) Tingkat pertambahan kualitas sarana dan prasarana umum.

b) Tingkat peningkatan kemandirian masyarakat secara ekonomi.

c) Tingkat penongkatan kualitas hidup bagi masyarakat secara berkelajutan.

a. Indikator Sosial

a) Frekuensi terjadinya gejolak sosial

b) Tingkat kualitas hubungan antara perusahaan dengan masyarakat

c) Tingkat kepuasan masyarakat (dilakukan dengan survei kepuasan). ${ }^{18}$

\section{Motif Perusahaan dalam Impementasi} Tanggung Jawab Sosial

Setiap perusahaan mempunya maksud dan tujuan tersendiri dalam melakukan atau pelaksanaan tanggung jawab soasial. Menurut, studi yang dilakukan oleh Nor Hadi, menujukan 62 perusahaan yang disurvei ternyata telah melaksanakantanggung jawab sosial, mulai dari bentuk kegiatan karitatif sampai pada kegiatan yang bersifat community development. ${ }^{19}$

4. Permasalahan yang timbul dari Implementasi Tanggung Jawab Sosial Perusahaan

a. Tanggung jawab Sosial diwajibkan dengan sanksi apabila tidak melaksankannya, meskipun peraturan pelaksanaannya belum ada.

Dengan adaya kewajiban Tanggung Jawab Sosial yang tadinya bersifat vouluntary atau sukarela sebagaimana dengan istilah yang digunakan, dalam Undang-Undang tentang Perseroan Terbatas diwajibkan untuk

\footnotetext{
${ }^{18}$ Ibid

${ }^{19}$ Nor Hadi, Interaksi Biaya Sosial, Kinerja Sosial, Kinerja Keuangan, dan Luas Pengungkaoan Sosial, " Uji Praktik Social Resposibility Perusahaan Go Publik di Bersa Efek Indonesia", Disertasi Universitas Diponegoro, hal 16
} 
melaksanakannya dan terdapat sanksi bila tidak dilaksanakan. Namun sekali lagi peraturan pelaksanaan dalam pemberian sanksi belum ada, kecuali terhadap kasuskasus yang besar yang terlebih dahulu merugikan lingkungan dan masyarakat banyak. ${ }^{20}$ Fungsi kontrol dari pemerintah yang masih sangat minim menyebabkan kurangnya praktek pelaksanaan dari tanggung jawab sosial, yang walaupun jelas-jelas terdapat sanksi sesuai dengan Undang-Undang tapi karena kurangnya kontrol, perusahaanpun enggan untuk melakukan tanggung jawab sosial.

\section{b. Tanggung Jawab Sosial dianggarkan kepada biaya perusahaan.}

Dilihat dari kemanfaatannya biaya sosial terdapat kemanfaatan jangka pendek dan jangka panjang, serta terdapat pengakuan yang memiliki potensi ekonomi di masa depan, maka biaya tanggung jawab sosial dikategorikan sebagai current expenditure dan capital expenditure. Menurut ISAK 3 menyatakan bahwa apabila biaya tanggung jawab sosial tidak bisa dikaitkan dengan perolehan suatu aktivitas, maka biaya tersebut harus dibebankan pada saat terjadinya dengan menggunakan dasar aktual. Pengeluaran current expenditure termasuk pada jenis biaya ini. ${ }^{21}$

Tanggung Jawab Sosial dianggarkan sebagai bagian dari biaya perusahaan. Pada umumnya tindakan sukarela Tanggung Jawab Sosial apabila perusahaan mendapat keuntungan, tetapi apabila dianggarkan kepada biaya perusahaan, ada kemungkinan perusahaan merugi, dan karena dianggarkan kepada biaya perusahaan maka harga produk akan lebih mahal. ${ }^{22}$ Anggaran perusahaan sendiri sangat banyak dan variatif antara lain:

\footnotetext{
${ }^{20}$ Djuhaendah Hasan, Op-Cit, hal.22

${ }^{21}$ Nor Hadi, Op-Cit, hal 209

${ }^{22}$ Ibid
}

c. Anggaran sebagai peralatan manajemen $^{23}$

d. Anggaran sebagai alat perencanaan dan pengawasan ${ }^{24}$

e. Anggaran komprehensif ${ }^{25}$

f. Anggaran penjualan ${ }^{26}$

g. Anggaran produksi ${ }^{27}$

h. Anggaran tenaga kerja ${ }^{28}$

i. Anggaran biaya operasi ${ }^{29}$

Dan berbagai macam anggaran perusahaan lainnya sesuai dengan bidang yang digeluti oleh perusahaan tersebut. Di sisi lainnya tidak ada batasan yang jelas sejauh mana suatu perusahaan harus melakukan tanggung jawab sosial, maupun batasan-batasan yang pasti dari tanggung jawab sosial itu sendiri.

\section{Pelaporan Program Tanggung Jawab Sosial}

Laporan tanggung jawab sosial merupakan laporan aktivitas tanggung jawab sosial yang telah dilakukan perusahaan baik berkaitan dengan perhatian masalah dampak sosial maupun lingkungan. Laporan tersebut menjadi bagian yang tidak terpisahkan dengan laporan tahunan (annual report) yang dipertanggung jawabkan direksi di depan siding Rapat Umum Pemegang Saham (RUPS). Laporan ini berisi laporan programprogram sosial dan lingkungan perseroan yang telah dilaksanakan selama tahun buku berakhir. $^{30}$

Mentri Badan Usaha Milik Negara (BUMN) lewat keputusan Nomor KEP04/MBU/2007 yang merupakan penyempurnaan dari surat Keputusan Menteri BUMN Nomor 236/MBU/2003

\footnotetext{
${ }^{23}$ Gunawan adisaputro \& Marwan Asri, "Anggaran Perusahaan", BPFE, Yogyakarta, 1998, edisi 3, hal.1

${ }^{24}$ Ibid hal.19

${ }^{25}$ Ibid hal.55

${ }^{26}$ Ibid hal.121

${ }^{27}$ Ibid hal.181

${ }^{28}$ Ibid hal. 257

${ }^{29}$ Ibid hal.318

${ }^{30}$ Nor Hadi, Op-Cit, hal 206
} 
tentang Program Kemitraan Badan Usaha Kecil dan Program Bina Lingkungan, memberikan arahan secara lebih operasional tentang praktik tanggung jawab sosial.

\section{B. Tanggung Jawab Sosial Perusahaan Real Estate di Daerah Manado}

1.Implementasi Tanggung Jawab Sosial Perusahaan Real Estate terhadap Masyarakat sesuai dengan UndangUndang

Dalam penjelasan tentang perusahaan yang harus menjalankan tanggung jawab sosial, Pasal 74 UU PT dijelaskan bahwa "Perseroan yang menjalankan kegiatan usahanya yang berkaitan dengan sumber daya alam adalah perseroan yang tidak mengelolah dan tidak memanfaatkan sumber daya alam, tapi kegiatan usahanya berdampak pada fungsi kemampuan sumber daya alam". ${ }^{31}$

Kaitannya dengan Peusahaan real estate adalah selain perusahaan real estate biasanya berbentuk Perseroan terbatas, sehingga harus tunduk kepada UU PT, namun pengelolaan perusahaan real estate itu sendiri membawa dampak pada kemampuan sumber daya alam (jumlah pohon dan luas lingkungan hijau). Sehingga dapat disimpulkan bahwa Perusahaan real estate merupakan perasahaan yang diwajibkan untuk melakukan Tanggung Jawab Sosial maupun Lingkungan.

\section{Studi Lapangan}

\section{a.Perumahan Puri Indah Permai II}

Perumahan Puri Indah Permai II merupakan perumahan yang berada di bawah naungan PT. Anugerah Trikarya lestari. Perumahan ini terletak di daerah Malalayang I timur dengan areal sebesar 25 hektar, dan direncanakan akan dibangun sekitar 800 unit rumah dengan tipe yang bervarian. Untuk sekarang ini baru

\footnotetext{
${ }^{31}$ Handri Raharjo, Op-Cit, hal. 90
}

dibangun 300 unit rumah dengan luas tanah sekitar 10 hektar.

Dari jumlah rumah dan luas tanah perumahan ini, maka kota Manado akan kehilangan 25 hektar lingkungan hijau dan digantikan dengan perumahan.

PT. Anugerah Trikarta Lestari (ATL) tidak memiliki visi, misi, maupun tujuan dalam implementasi Tanggung Jawab Sosial, walaupun memang di dalam areal perumahannya terdapat berbagai saranasarana yang ditujukan untuk kebutuhan masyarakat, atau dapat membantu masyarakat.

Menurut developer dan pemilik P.T ATL "sarana yang dibangun hanya sesuai dengan ketentuan yang diminta oleh Dinas tata kota dan daya tarik perumahan untuk menambah user atau pembeli rumah saja, bukan dikhususkan untuk Tanggung Jawab Sosial perusahaannya"32.

Padahal tanggung jawab sosial dan lingkungan yang merupakan komitmen dari perseroan adalah alat yang digunakan untuk meningkatkan kualitas kehidupan dan lingkungan yang bermanfaat, bagi Perseroan sendiri, komunitas setempat maupun masyarakat pada umumnya. ${ }^{33}$

Adapun beberapa program yang telah P.T ATL lakukan adalah:

1) Membuat ruang terbuka hijau (sesuai dengan permintaang Dinas Tata Kota)

2) Membuat taman (sesuai denganpermintaan Dinas Tata Kota)

3) Pembangunan Sekolah TK gratis

4) Pembangunan Gereja

5) Pembangunan Taman Bermain

6) Jamsostek (untuk karyawan)

Selain berbagai fasilitas yang dibangun oleh perumahan tersebut, perumahan ini kurang memperhatikan lingkungan sekitar, dimana tidak disediakannya sarana

\footnotetext{
${ }^{32}$ Wawancara: Suntje Liem, Direktur PT. Anugrah Trikarya Lestari

${ }^{33}$ Djuhaendah Hasan, Op-Cit, hal. 14
} 
pembuangan sampah bagi para penghuni rumah, sehingga para penghuni perumahan membakar sampah-sampah rumah tangga yang mereka hasilkan. Hal ini tentu saja sangat mempengaruhi lingkungan sekitar dan akan memberikan sumbangsi terhadap polusi udara yang kemudian memperparah global warming. Bisa disimpulkan bahwa perumahan ini masih kurang mementingkan kebersihan lingkungan.

\section{b. Hasil Pengumpulan Data Kuisioner ${ }^{34}$}

Sesuai dengan pengumpulan data yang telah terkumpul melalui lembaran kuisioner, seluruh perumahan yang ditinjau memiliki tanggung jawab sosial terhadap produk atau rumah yang dijual dengan baik, mulai dari kualitas, layanan dan prosedur produksi rumah tersebut.

Dari segi tanggung jawab lingkungan sendiri, 7 dari 10 perumahan yang telah di survey telah melakukan upaya-upaya perlindungan terhadap lingkungan, mulai dari investasi pengelolahan limbah, manajemen dan tata lingkungan, mengelolah limbah dan merehabilitasi lingkungan dalam kawasan perumahan.

Dari segi tanggung jawab komunitas, 6 dari 10 perumahan yang telah disurvei telah melakukan bantuan-bantuan terhadap komunitas atau penghuni perumahan, seperti perbaikan jalan, air bersih, bantuan bagi saran ibadah, bantuan kesehatan, bantuan koperasi dan sebagainya.

Namun hampir seluruh upaya dan bantuan, serta fasilitas yang dibangun oleh perusahaan real estate tersebut yang ditujukan bagi penghuni perumahan atau konsumen saja. Dari 10 perusahaan real estate atau perumahan di daerah Manado yang telah disurvei, semuanya setidaknya telah menjalankan 3 jenis tanggung jawab sosial namun hanya 2 dari 10 perusahaan saja yang menjalankan Tanggungung jawab

\footnotetext{
${ }^{34}$ Lembaran Kuisioner
}

sosial dan lingkungan sesuai dengan pasal 3 Peraturan Pemerintah No.40 tahun 2012, yaitu:

1) Tanggung jawab sosial dan lingkungan sebagaimana dimaksud dalam Pasal 2 menjadi kewajiban bagi Perseroan yang menjalankan kegiatan usahanya di bidang dan/atau berkaitan dengan sumber daya alam berdasarkan UndangUndang.

2) Kewajiban sebagaimana dimaksud pada ayat (1) dilaksanakan baik di dalam maupun di luar lingkungan Perseroan.

Sebagian besar Perusahaan real estate di daerah Manado yang telah disurvei hanya melakukan tanggung jawab sosial yang berupa fasilitas bagi konsumen atau pemilik rumah yang kemudian tidak memberikan sumbangsi apapun bagi masyarakat yang berada disekitar perumahan.

\section{Ketentuan Hukum Terkait dan Pemberlakuannya}

Sesuai dengan pasal dengan pengertian dan penjelasan tentang tanggung jawab sosial dan lingkungan maka setiap perseroan dan penanam modal baik asing maupun luar negeri yang kegiatan usahanya di bidang dan atau berkaitan dengan sumber daya alam berkewajiban untuk menjalankan tanggung jawab sosial dan lingkungan. Ketentuan ini di atur dalam:

a. Pasal 74 ayat 4 Undang-Undang No.40 Tahun 2007 tentang Perseroan Terbatas

b. Pasal 34 ayat 1 Undan-Undang No.25 tahun 2007 tentang Penanaman Modal

c. Pasal 3 Peraturan Pemerintah Republik Indonesia tentang Tanggung Jawab Sosial dan Lingkungan.

Dalam hal ini setiap perusahaan yang memiliki kewajiban dalam melaksanakan tanggung jawab sosial dan lingkungan akan dikenankan sanksi sesuai dengan UndangUndang yang berlaku, yaitu pada pasal 34 
ayat 1 Undang-Undang Penanaman Modal No.25 tahun 2007

Pasal 34

(1) Badan usaha atau perseorangan sebagaimana dimaksud dalam pasal 5 yang tidak memenuhi kewajiban sebagaimana yang ditentukan dalam pasal 15 dapat dikenakan sanki administratif berupa:

a. Peringatan tertulis

b. Pembatasan kegiatan usaha

c.Pembekuan kegiatan usaha dan/atau fasilitas penanaman modal; atau

d. Pencabutan kegiatan usaha dan/atau fasilitas penanaman modal.

Ketentuan-ketentuan hukum yang telah tercantum dalam pasal-pasal di atas sudah sangat jelas, mulai dari pengertiannya sampai pada sanksi yang dapat diberikan bila tidak dilaksanakan. Dalam hal ini pemerintah telah memberikan kepastian hukum atau mengatur suatu terobosan dalam dunia usaha agar para pelaku usaha dapatmelakukan tanggung jawab sosial dan lingkungan dalam rangka kemajuan dan kesejahteraan masyarakat sekitar dan lingkungan.

Namun sesuai dengan hasil survei yang telah dilakukan, ternyata di daerah Manado sendiri banyak perusahaan, dan khususnya yang bergerak dibidang real estate yang tidak melakukan tanggung jawab sosial dan lingkungan namun tidak menerima sanksi seperti yang telah diatur dalam Undangundang penanaman modal.

Berbagai faktor menjadi penyebab dari kurangnya pelaksanaan tanggung jawab sosial, mulai dari kurangnya pengertian dari para developer sendiri tentang kewajiban yang mereka miliki maupun ketikdatahuan akan Undang-Undang itu sendiri. Di sisilain penjelasan dari Undang-Undang tanggung jawab sosial yang kurang jelas tentang perusahaan yang berkaitan dengan sumber daya alam dan tidak adanya peran serta dari pemerintah atau instansi yang bersangkutan.

\section{PENUTUP}

\section{A. KESIMPULAN}

1. Bahwa perusahaan yang walaupun kegiatan usaha yang dijalankan tidak mengelola dan memanfaatkan sumber daya alam, tetapi kegiatan usahanya bermpak pada kemampuan sumber daya alam memiliki tanggung jawab yang sama dengan perusahaan yang bergerak dibidang sumber daya alam dan meskipun tanggung jawab sosial dan lingkungan perusahaan telah ditetapkan dan diundangkan, namun tidak serta merta membuat para pelaku usaha mengimplementasikan kewajiban mereka untuk menjalankan tanggung jawab sosial sesuai dengan UndangUndang yang telah diatur oleh pemerintah, karena di sisi lain tidak ada batasan yang jelas tentang tanggung jawab sosial dan lingkungan itu sendiri.

2. Bahwa di daerah Manado sendiri, kesadaran dari pelaku-pelaku usaha masih kurang dalam pelaksanaan tanggung jawab sosial dan lingkungan, dimana perusahaan yang bergerak dibidang real estate (perusahaan yang kegiatan usahanya berdampak pada kemampuan sumber daya alam) dalam hal ini tidak melaksanakan tanggung jawab sosial dan lingkungan untuk kesjahteraan masyarakat sekitar perusahaan ataupun masyarakat luas dan meskipun tidak adanya pelaksanaan tanggung jawab sosial dan lingkungan dari perusahaan real estate di daerah Manado, tidak adan tindak lanjut dari pemerintah setempat dalam pemberian saksi sesuai dengan Undang-Undang yang telah ada.

\section{B. SARAN}

1. Perlu adanya inisyatif dan perencanaan yang matang oleh perusahaan dalam melakukan tanggung jawab sosial, agar usaha yang dilakukan tepat pada sasaran serta memenuhi kebutuhan masyarakat 
dan lingkungan sekitar, serta penjelasan dan pemahaman yang lebih konkrit akan perusahaan yang berkaitan dengan sumber daya alam, agar tanggung jawab sosial dan lingkungan tidak hanya dititik beratkan kepada para pelaku usaha yang bergerak dibidang sumber daya alam tapi juga kepada perusahaan yang kegiatan usahanya berkaitan dengan sumber daya alam agar maksud dari Undang-Undang itu sendiri bisa diimplementasikan kepada kedua bidang usaha, yang sama-sama mempengaruhi keselarasan sosial dan lingkungan, walaupun dampaknya tidak sama.

2. Perlu adanya fungsi kontrol atau suatu badan pengawasan dari pemerintah maupun instatansi yang bersangkutan, terhadap perusahaan-perusahaan yang diwajibkan untuk melakukan tanggung jawab sosial dan lingkungan, agar para pelaku usaha bisa lebih terdorong lagi dalam menjalankan kewajiban mereka terhadap tanggung jawab sosial dan lingkungan, serta pelaksanaan saksi yang konkrit ketika suatu perusahaan tidak melakukan tanggung jawab mereka dibidang sosial dan lingkungan.

\section{DAFTAR PUSTAKA}

Adisaputro, Gunawan dan Astri, Marwan, "Anggaran Perusahaan", BPFE, Yogyakarata, 1998, Edisi 3.

Azhari, Sitty Kusumawati, "Norma Hukum dan Bisnis Tanggung Jawab Sosial Perusahaan", Jurnal Sosioteknologi, 2007, Edisi 2007.

Belkaou. A dan Kaprik, "The Impact of Sosial Economis Accointing Statement on the Investment Decision: An Empirical Study", Vol 1.

Hadi, Nor, "Corporate Social

Responsibility", Graha IImu, Yogyakarta, 2011.

......, Interaksi Biaya Sosial, Kinerja Sosial, Kinerja Keuangan, dan Luas Pengungkaoan Sosial, " Uji Praktik Social
Resposibility Perusahaan Go Publik di Bersa Efek Indonesia", Disertasi Universitas Diponegoro.

Hasan, Djuhaendah, "Tanggung Jawab Sosial Perusahaan", Badan Pembinaan Hukum Nasional Departemen Hukum dan Ham Republik Indonesia, Jakarta, 2009.

Kansil, Christine, "Hukum Perusahaan Indonesia", PT. Pradnya Paramita, Jakarta, 2001.

Kaligis, O.C, " Antologi Tulisan IImu Hukum", PT. Alumni, Bandung, 2011.

Purwosutjipto, "Pengertian Pokok Hukum Dagang Indonesia", Jambatan, Jakarta, 1984.

Raharjo, Handri, "Hukum Perusahaan", Pustaka Yustisia, Yogyakarta, 2009.

Sambodo, Basuki, "Pedoman Corporate Sosial Responsibility Bidang Lingkungan", Jakarta.

Sembiring, Sentosa, "Hukum Perusahaan Dalam Peraturan Undang-Undang", Nuansa Aulia, Bandung, 2006.

Sukarni. S.H, MH, "Tanggung Jawab Sosial Perusahaan (CSR) dan Iklim Penanaman Modal", 4 Januari 2010.

Suprani, Niniek, " Kitab Undang - Undang Hukum Dagang dan Kepailitan", Rineka Cipta, Jakarta, 2003.

“Undang- Undang R.I Nomor 40 Tahun 40 Tentang Perseroan Terbatas", Citra Umbara, Bandung, 2007.

Wibisono, Yusuf, "Membedah Konsep dan Apikasi Corporate Sosial Responsibility", Fascho Publishing, Jawa Timur, 2007. 